\title{
EFFECT OF THE POSTHARVEST PROCESSING METHOD ON THE BIOCHEMICAL COMPOSITION AND SENSORY ANALYSIS OF ARABICA COFFEE
}

\author{
Yeison F. B. Rodriguez ${ }^{1}$, Nelson G. Guzman ${ }^{1 *}$, Joel G. Hernandez ${ }^{1}$ \\ ${ }^{1 *}$ Corresponding author. Universidad Surcolombiana/ Neiva, Colombia. \\ E-mail: ngutierrezg@usco.edu.co | ORCID ID: https://orcid.org/0000-0003-2499-8066
}

\section{KEYWORDS}

caffeine, coffee roasting, coffee processing, cup quality, chlorogenic acids.

\begin{abstract}
The objective of this work was to study the influence of two postharvest processing methods on the biochemical composition and sensory analysis of a Colombian specialty coffee. For this purpose, coffee beans (Coffea arabica) of the Castillo variety were collected and processed using the wet and semi-dry methods, and the drying process was conducted in a sun drier prototype with a plastic parabolic cover, with a maximum drying air temperature of $50{ }^{\circ} \mathrm{C}$; green coffee beans were managed according to the official Specialty Coffee Association cupping protocol and roasted to a medium and dark degree. Physicochemical determinations $(\mathrm{pH}$, color, titratable acidity, caffeine content, and chlorogenic acid quantification) in green coffee and roasted coffee beans were performed; the sensory analysis was performed by a panel of trained tasters. The wet and semi-dry processing methods resulted in differences in color parameters, $\mathrm{pH}$ values, and caffeine content. However, the titratable acidity, chlorogenic acid, and sensory evaluation did not have any difference; therefore, the type of coffee processing method used is not relevant to the final chemical properties of the roasted coffee (i.e., the Castillo variety) evaluated in this study; the coffee cup score is also not affected, and the post-fermentation washing process can be dispensed with.
\end{abstract}

\section{INTRODUCTION}

The sensory characteristics of Colombian coffee imbue it with one of the highest prices on the international market (Barjolle et al., 2017). At the end of 2018, Colombian coffee production exceeded 13.5 million bags (Federación Nacional de Cafeteros, 2019), a figure that positions the country as the third largest producer of coffee worldwide. Colombia contains different coffee producing regions, with one of them being the department of Huila; its ideal agro-ecological characteristics for cultivation have made it the highest coffee producing area. Among the varieties of coffee that have the highest volume of production is the Castillo variety; its agronomic attributes offer a tolerance of coffee leaf rust (Hemileia vastatrix) in regions at elevations below $1600 \mathrm{~m}$ above sea level. In areas with an elevation higher than $1600 \mathrm{~m}$ where the incidence of rust decreases, the Castillo variety has greater productive potential (Alvarado et al., 2005). The department of Huila is known for its production of specialty coffees whose exceptional sensory characteristics and cup profile are associated with small-scale harvests and good agricultural practices (Di Donfrancesco et al., 2019). Postharvest processing is thought to be a key factor contributing to a high-quality coffee. Coffee beans are processed either by the wet, semi-dry, or dry method (Duarte et al., 2010). The wet process is the most common in Colombia; it removes the mucilage by adding water. The main disadvantage of this method lies in the disposal of the waste generated by coffee processing, where both wet pulp and water solutions with a high content of organic load are discharged, thus modifying the acidity of the water supply, which in turn increases the turbidity as a consequence of the large amount of suspended solids (Vellema et al., 2015).

In the semi-dry method, beans are fermented but not washed. Washing is a step that can be omitted since it does not affect the quality of the cup; environmental impact and production costs are however reduced (Dadi et al., 2018). Once the parchment is obtained, beans then continue to the roasting process; varying levels of roast, depending on the preferences of the consumer, are delivered. In Colombia, two levels of roast stand out: medium and dark. Medium roasts result in a more

\footnotetext{
${ }^{1}$ Universidad Surcolombiana / Neiva, Colombia.
} 
balanced aroma and flavor, while coffees with a higher level of roast deliver stronger flavors which mask some of the defects in the final drink (SCAA, 2015). The aim of this study is to evaluate the effects of wet and semi-dry processing methods on the chemical composition of Castillo variety coffee samples, for green coffee, medium roast, and dark roast; the effects of fermentation processing in sensory evaluation are also examined.

\section{MATERIAL AND METHODS}

\section{Samples}

Forty kilograms of coffee cherries of the Castillo variety (Coffea arabica) were harvested at an altitude of $1650 \mathrm{~m}$ above sea level; only beans with an intense red coloration were selected. The samples were deposited in polystyrene containers with cooling gels to avoid early fermentation and were later transported to the coffee processing pilot plant at the Universidad Surcolombiana; $20 \mathrm{~kg}$ of coffee cherries were processed with the wet method, and the remaining $20 \mathrm{~kg}$ were processed using the semi-dry method, and in both cases the fermentation process was carried out at room temperature $\left(27 \pm 4{ }^{\circ} \mathrm{C}\right)$. Fermentation began, for both methods, at a $\mathrm{pH}$ of $5.81 \pm$ 0.014 , and continued until a $\mathrm{pH}$ of $4.59 \pm 0.107$ was reached. Subsequently, the drying process was carried out in a prototype sun dryer with a plastic polyethylene transparent parabolic cover; a temperature of $50{ }^{\circ} \mathrm{C}$ is reached in the dryer, and the moisture content of the samples was reduced to $11.3 \%$ (w.b.) \pm 0.05 and $11.0 \%$ (w.b.) \pm 0.10 for the wet and semi-dry processes, respectively. The hulling process was carried out in a laboratory hulling machine (ING-C-200, Ingesec, Bogotá, Colombia), followed by the selection of non-defective coffee beans (Tolessa et al., 2016). The coffee beans were passed through a No. 13 sieve with a diameter of $5 \mathrm{~mm}$ to eliminate the smaller beans, for both process methods. The non-defective green coffee beans, obtained by processing $20 \mathrm{~kg}$ of cherry coffee, were divided into two equal parts, to be roasted in a Laboratory Quantik roaster (TC-150R, Quantik, Colombia); $150 \mathrm{~g}$ batches of green coffee for each process method were put in the roaster machine to an entry temperature of $180{ }^{\circ} \mathrm{C}$, with two levels of roasting defined according to luminosity $\left(L^{*}\right)$ measurements: medium $\left(21.0<L^{*}<23.5\right)$ and dark $\left(19.0<L^{*}<21.0\right)$ roasts (Craig et al., 2012); all assays were carried out in triplicate.

\section{Analytical determinations}

\section{Color}

The colors of the green and roasted samples were obtained using a Konica Minolta colorimeter (CR-410, N.J., USA), represented in the coordinates $L^{*}, a^{*}$, and $b^{*}$ (Commission Internationale de l'Éclairage, CIE).

\section{pH and titratable acidity}

The $\mathrm{pH}$ was determined by a properly calibrated $\mathrm{pH}$ meter with a glass electrode (Starter 5000, OHAUS, USA) for an extract of $2.25 \mathrm{~g}$ of ground coffee in $50 \mathrm{ml}$ of water at $80{ }^{\circ} \mathrm{C}$, which was then brought to room temperature to perform the measurement (Mazzafera, 1999). Titratable acidity was evaluated by titration with $\mathrm{NaOH}$, according to AOAC (1995). The results were expressed in milligrams $(\mathrm{mg})$ of chlorogenic acids in relation to grams $(\mathrm{g})$ of coffee.

\section{Chlorogenic acids and caffeine}

The determination of chlorogenic acid (CGA) and caffeine content was performed by HPLC (LaChrom Elite Hitachi Ltd., Tokyo, Japan) equipped with a self-sampler (model L-2200) and a UV detector (model L)-2400). The separation was carried out for 24 min with a C18 column $(150 \times 4.6 \mathrm{~mm}$ i.d. $5 \mu \mathrm{m})$ (Scharlab, Barcelona, Spain). In the mobile phases a gradient of $\mathrm{MeOH}$, water, and glacial acetic acid was used. Readings were made for chlorogenic acid at $324 \mathrm{~nm}$ and for caffeine at $280 \mathrm{~nm}$; in both cases, $200 \mu \mathrm{l}$ was injected at a flow rate of $1 \mathrm{ml} / \mathrm{min}$.

\section{ATR-FTIR analysis}

The spectrum measurements were made with an ART-FTIR CARY 630 spectrometer (Agilent, Santa Clara, CA, USA), between the wavelengths $3100-800\left(\mathrm{~cm}^{-1}\right)$, with a resolution of $4 \mathrm{~cm}^{-1}$, and 20 scanners. Once the spectra were obtained, the areas of reported peaks of interest for caffeine, CGA, and lipids were integrated with the Resolution Pro FTIR software (Agilent, Santa Clara, CA, USA).

\section{Sensory analysis}

The sensory analysis was performed by 10 trained tasters, with five cups per treatment, according to the methodology established by Di Donfrancesco et al., 2014; the sensory analyses were conducted only for the semi-dry and wet methods with a medium level roaster, owing to the specifications of the SCA Protocol.

\section{Statistical analysis}

The results of the analytical and sensory determinations were processed from an analysis of the variance (one-way or multifactor ANOVA) with a confidence level of $95 \%$. Mean comparison analyses were performed to identify statistically significant differences of the parameters evaluated between the different categories. The statistical procedures were carried out with Statgraphics Centurion XVI (Manugistics Inc., Rockville, MD, USA).

\section{RESULTS AND DISCUSSION}

Table 1 shows the mean values and the standard deviation for the physicochemical parameters. When evaluating the effect of the degree of roast, significant differences were found $(\mathrm{p}<0.05)$ for all the parameters, mainly due to the occurrence of multiple chemical reactions during the roasting process. Regarding the effect of the type of processing method, there were significant differences $(p<0.05)$ for the parameters of color, $\mathrm{pH}$, and caffeine. 
TABLE 1 . Mean values \pm standard deviation of color parameters $L^{*}$ : lightness, $a^{*}$ : redness, $b^{*}$ : yellowness, $\mathrm{pH}$, titratable acidity, CGA, and caffeine, in green and roasted samples.

\begin{tabular}{|c|c|c|c|c|c|c|c|c|}
\hline & \multicolumn{3}{|c|}{ Wet process } & \multicolumn{3}{|c|}{ Semi-dry process } & \multicolumn{2}{|c|}{$\alpha$} \\
\hline & Green coffee & Medium roast & $\begin{array}{l}\text { Dark } \\
\text { roast }\end{array}$ & Green coffee & $\begin{array}{c}\text { Medium } \\
\text { roast }\end{array}$ & $\begin{array}{l}\text { Dark } \\
\text { roast }\end{array}$ & (R) & (P) \\
\hline $\mathrm{L}^{*}$ & $43.8 \pm 0.3 \mathrm{Aa}$ & $24.5 \pm 0.4 \mathrm{Ba}$ & $20.5 \pm 0.1 \mathrm{Ca}$ & $44.5 \pm 0.3 \mathrm{Aa}$ & $24.8 \pm 0.4 \mathrm{Ba}$ & $21.4 \pm 0.3 \mathrm{Ca}$ & $* * *$ & $\begin{array}{l}\mathrm{ns} \\
\mathrm{ns} \\
\mathrm{ns}\end{array}$ \\
\hline$a^{*}$ & $1.7 \pm 0.1 \mathrm{Aa}$ & $9.0 \pm 0.1 \mathrm{Ba}$ & $7.1 \pm 0.1 \mathrm{Ba}$ & $2.3 \pm 0.1 \mathrm{Aa}$ & $8.7 \pm 0.3 \mathrm{Ba}$ & $7.3 \pm 0.1 \mathrm{Ba}$ & $* * *$ & $\begin{array}{l}\mathrm{ns} \\
\mathrm{ns} \\
\mathrm{ns}\end{array}$ \\
\hline$b^{*}$ & $11.8 \pm 0.1 \mathrm{Aa}$ & $9.5 \pm 0.1 \mathrm{Ba}$ & $6.2 \pm 0.1 \mathrm{Ca}$ & $13.6 \pm 0.1 \mathrm{Ab}$ & $9.4 \pm 0.3 \mathrm{Ba}$ & $6.6 \pm 0.1 \mathrm{Ca}$ & $* * *$ & $\begin{array}{l}\mathrm{ns} \\
\mathrm{ns}\end{array}$ \\
\hline $\mathrm{pH}$ & $6.1 \pm 0.1 \mathrm{Aa}$ & $4.9 \pm 0.1 \mathrm{Ba}$ & $5.0 \pm 0.1 \mathrm{Ca}$ & $6.1 \pm 0.1 \mathrm{Aa}$ & $4.8 \pm 0.1 \mathrm{Bb}$ & $4.8 \pm 0.2 \mathrm{Cb}$ & $* * *$ & $\begin{array}{c}\mathrm{ns} \\
* * * \\
* * *\end{array}$ \\
\hline Titratable Acidity & $3.1 \pm 0.2 \mathrm{Aa}$ & $36.5 \pm 0.7 \mathrm{Ba}$ & $37.9 \pm 0.7 \mathrm{Ca}$ & $2.9 \pm 0.1 \mathrm{Aa}$ & $37.9 \pm 2.1 \mathrm{Ba}$ & $37.2 \pm 1.4 \mathrm{Ba}$ & $* * *$ & $\begin{array}{l}\mathrm{ns} \\
\mathrm{ns} \\
\mathrm{ns}\end{array}$ \\
\hline $\begin{array}{l}\text { CGA } \\
\mathrm{mg} / \mathrm{g}\end{array}$ & $48.9 \pm 0.9 \mathrm{Aa}$ & $8.8 \pm 0.2 \mathrm{Ba}$ & $8.0 \pm 0.1 \mathrm{Ba}$ & $50.4 \pm 2.2 \mathrm{Aa}$ & $9.7 \pm 0.4 \mathrm{Ba}$ & $8.7 \pm 1.1 \mathrm{Ba}$ & $* * *$ & $\begin{array}{l}\mathrm{ns} \\
\mathrm{ns} \\
\mathrm{ns}\end{array}$ \\
\hline $\begin{array}{l}\text { Caffeine } \\
\mathrm{mg} / \mathrm{g}\end{array}$ & $29.9 \pm 0.9 \mathrm{Aa}$ & $17.0 \pm 0.1 \mathrm{Ba}$ & $17.2 \pm 0.5 \mathrm{Ba}$ & $35.6 \pm 0.9 \mathrm{Ab}$ & $14.1 \pm 0.6 \mathrm{Bb}$ & $13.3 \pm 1.3 \mathrm{Bb}$ & $* * *$ & $\begin{array}{l}* * \\
* * \\
* *\end{array}$ \\
\hline
\end{tabular}

Different uppercase letters indicate significant differences for roasting levels (R). Different lowercase letters indicate significant differences for the processing method (P). ns: not significant. ${ }^{*} \mathrm{p}<0.05 .{ }^{* *} \mathrm{p}<0.01$. ${ }^{* * *} \mathrm{p}<0.001$.

In the color coordinates $\mathrm{L}^{*}, \mathrm{a}^{*}$, and $\mathrm{b}^{*}$ in green coffee, the samples of the semi-dry processing method presented higher values than the samples of the wet processing method; this is due to the fact that the beans had dried with adhering mucilage, enhancing the values of the color coordinates; these differences, attributable to the processing method, are not found in roast beans, even in beans with mucilage, because of the caramelization reactions that generate the homogeneous brown color. In fact, the effect of the temperature decreases the differences caused by the mucilage residues. Other authors (Lee et al., 2017) have reported similar results. The $\mathrm{pH}$ values were higher for the samples obtained with the wet processing method. There were significant differences $(p<0.05)$ between the postharvest processing method and the roasted samples; with longer roasting times (dark roasting), the $\mathrm{pH}$ values increased (Daglia et al., 2000; Duarte et al., 2005); this increase in $\mathrm{pH}$ alters the degree of ionization of the chemical compounds that improve the taste of the beverage (Ky et al., 2001). Regarding the values of titratable acidity and CGA content, the type of processing method does not have any significant effect $(p>0.05)$; however, it was observed that as the degree of roasting increases, the CGA content decreases and titratable acidity increases, which represents an inverse relationship between the two variables. The values found for CGA in green coffee are within the ranges reported by other authors (Ky et al., 2001; Farah et al., 2005; Moon et al., 2009; Hečimović et al., 2011; Han et al., 2017; Worku et al., 2017). In the roasting step, processing speed is related to time and temperature, variables that also affect the CGA content in coffee beans. The higher the processing speed, the lower the CGA loss (Farah \& Duarte, 2015), which is evidenced in the magnitudes obtained for the two postharvest processing methods: $8.828 \pm 0.197 \mathrm{mg} / \mathrm{g}$ medium roast and $8.021 \pm 0.111 \mathrm{mg} / \mathrm{g}$ dark roast for the wet processing method, $9.661 \pm 0.429 \mathrm{mg} / \mathrm{g}$ medium roast and $8.754 \pm 1.145 \mathrm{mg} / \mathrm{g}$ dark roast for the semi-dry processing method.

The values obtained for the caffeine content were higher in the green coffee samples, as compared to the roasted samples; this is because the observed caffeine content can be influenced by the roasting process (Burdan, 2015). The samples of medium roast and dark roast processed with the semi-dry processing method presented the lowest levels of caffeine $(14.11 \pm 0.61 \mathrm{mg} / \mathrm{g}$ and 13.33 $\pm 1.34 \mathrm{mg} / \mathrm{g}$ ); however, the level of caffeine observed in green coffee beans had the lowest values in samples utilizing the wet method. The measured values of caffeine in green coffee are comparable with the ranges reported by Liang et al. (2016), and by Jeszka-Skowron et al. (2016), while for medium and dark roasts the levels are in the range described for arabica coffee by Wang \& Lim (2015). Caffeine levels are relatively stable despite being subjected to heat during roasting (Garg, 2015), although lower values tend to be present in coffee with dark roasts than in coffee with lower roasts (Wang and Lim, 2015), as evidenced by the values of caffeine acquired from the roasted samples using the semi-dry processing method of this study. 
While performing the analysis for the results of the multifactor ANOVA (Table 2), it was observed that the degree of roasting presented differences $(\mathrm{p}<0.05)$ for all of the evaluated parameters; the postharvest processing method factors showed significant differences $(\mathrm{p}<0.05)$ for the color coordinate $\mathrm{a}^{*}, \mathrm{pH}$, and caffeine. The interaction of the factors $(\mathrm{RxP})$ was significant $(\mathrm{p}<0.05)$ for the color coordinate $\mathrm{b}^{*}, \mathrm{pH}$, and the titratable acidity.

TABLE 2. F-ratio and significance levels, obtained in multifactor ANOVA, for the physicochemical parameters according to the factors: degree of roasting $(\mathrm{R})$ and process $(\mathrm{P})$ and their interaction $(\mathrm{R} \times \mathrm{P})$.

\begin{tabular}{cccc}
\hline & $\mathrm{R}$ & $\mathrm{P}$ & $\mathrm{R} \times \mathrm{P}$ \\
\hline $\mathrm{L}^{*}$ & $2210.80^{* * *}$ & $15.70^{* *}$ & $1.59^{\mathrm{ns}}$ \\
$\mathrm{a}^{*}$ & $3296.78^{* *}$ & $5.835^{*}$ & $13.52^{*}$ \\
$\mathrm{~b}^{*}$ & $235.00^{* * *}$ & $2.28^{\mathrm{ns}}$ & $5.47^{* *}$ \\
$\mathrm{pH}$ & $45312.64^{* * *}$ & $327.27^{* * *}$ & $187.36^{* * *}$ \\
Titratable Acidity & $4212.83^{* * *}$ & $1.43^{\mathrm{ns}}$ & $10.56^{* *}$ \\
CGAs & $1233.85^{* * *}$ & $1.68^{\mathrm{ns}}$ & $3.12^{\mathrm{ns}}$ \\
$\mathrm{mg} / \mathrm{g}$ & $25.26^{* * *}$ & $66.49^{* * *}$ & $3.19^{\mathrm{ns}}$ \\
\hline
\end{tabular}

ns: not significant. $* * \mathrm{p}<0.01 . * * * \mathrm{p}<0.001$

\section{ATR- FTIR analysis}

Figure 1 shows the spectra of the green coffee samples and the roasted samples, for the two postharvest processing methods. For CGA, authors have related the bands of $1700-1600 \mathrm{~cm}^{-1}$ (Ribeiro et al., 2010), however, because CGA is a family of esters formed between certain transcinamic acids and quinic acid (Clifford, 2000), absorption is present in the region of $1450-1000 \mathrm{~cm}^{-1}$ (Lyman, 2003).

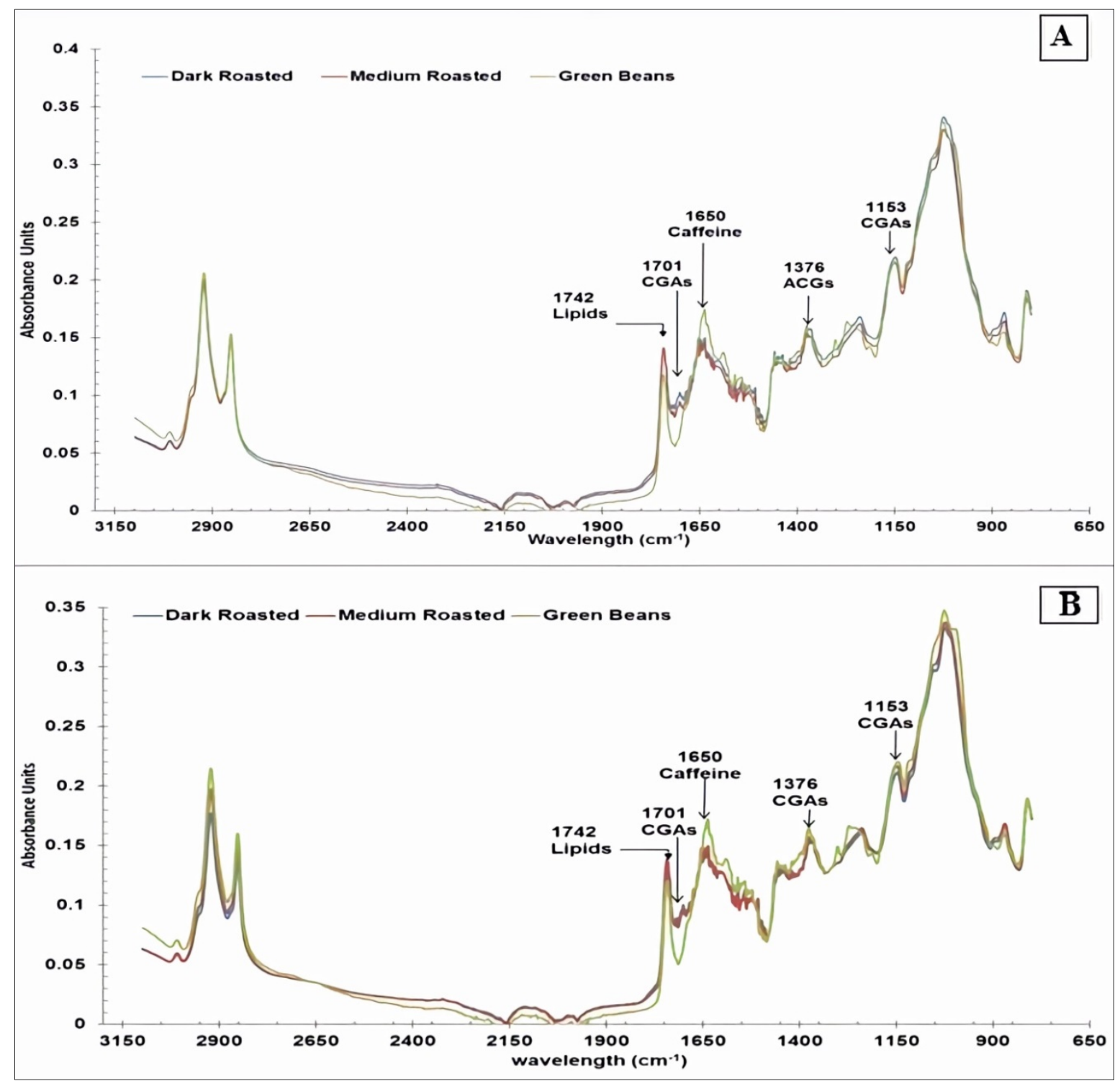

FIGURE 1. Average ATR-FTIR spectra from green, medium roasted, and dark roasted coffee. (A) wet process and (B) semi-dry process 
The $\mathrm{C}-\mathrm{O}$ axial deformation of quinic acid occurs in the range of $1085-1050 \mathrm{~cm}^{-1}$. Within this range, the band $1067 \mathrm{~cm}^{-1}$ is attributed to structures of pyruvic acid, pyridine, and quinic acid (Dias et al., 2018). The ester bond C-O-C is also absorbed in the range of 1300-1000 $\mathrm{cm}^{-1}$; this may be partially due to chlorogenic acids (Craig et al., 2012). The above information agrees with both the absorbance peaks obtained in the samples studied and the range of 1450-1000 $\mathrm{cm}^{-1}$ reported by Reis et al. (2013). The obtained results show that in the length of $1701 \mathrm{~cm}^{-1}$ the peak obtained was more acute for the green coffee samples compared to the roasted coffee samples; additionally, at the wavelength of $1376 \mathrm{~cm}^{-1}$, a change in the shape of the peak was observed; this generated higher values in the quantification of the areas by the Resolution Pro software (Table 3). When comparing the quantification of the areas with the concentrations obtained by the HPLC method, it was observed that green coffee samples have a higher CGA content, and the ATR-FTIR technique did not differentiate between the medium and dark roast samples.

In relation to caffeine; records related to the 1659 $\mathrm{cm}^{-1}$ band have been reported (Lyman et al., 2003; Craig et al., 2012); in this study, the band moved to $1650 \mathrm{~cm}^{-1}$ which is agreement with the range of $1650-1600 \mathrm{~cm}^{-1}$ of the infrared spectrum (Gallignani et al., 2008; Craig et al., 2014) region in which the cyclic amides absorbing caffeine content showed significant differences in the integration of the areas. The green coffee samples showed the highest values which relates the decrease or proportion of caffeine directly to the coffee's degree of roast. Additionally, Figure 1 shows that the caffeine peak is much more pronounced for the green coffee samples compared to the peaks obtained for the two degrees of roasting.
The mean value of the areas involved at the 1742 $\mathrm{cm}^{-1}$ wavelength, in the green and roasted coffee samples, showed no difference $(\mathrm{p}>0.05)$; this wavelength is associated with an aliphatic ester to the $\mathrm{C}-\mathrm{O}$ carbonyl vibration; therefore, its presence in the medium infrared spectrum can be attributed to the presence of lipids (Lyman et al., 2003; Gallignani et al., 2008), which is also related to $\mathrm{C}=\mathrm{O}$ stretching and to different functional groups including aliphatics, aromatic acids, aldehydes, ketones, and lactones, all of which are compounds that give different aromas to coffee, making it an important region of the spectrum (Craig et al., 2015).

\section{Sensory analysis}

The coffee postharvest processing method did not affect the total cup score, for the Castillo variety evaluated in this study ( $>0.05$ ); the mean value for the semi-dry processing method was $85.938 \pm 0.569$, while the value for the wet processing method was $84.125 \pm 0.415$; therefore both treatments could be defined as specialty coffees.

All of the individually evaluated attributes (Figure 2) did not present any differences ( $p>0.05)$, but it was evident that the results for the attributes of fragrance / aroma, aftertaste, acidity, and body that resulted from wet processing method were, on average, higher than the samples processed with the semi-dry processing method. In addition, it was observed that the parameters of uniformity, balance, clean cup, and sweetness increased the overall rating. Finally, this result confirms that the cupping protocol is only designed to evaluate the quality threshold used to classify samples as specialty coffees (Di Donfrancesco et al., 2014).

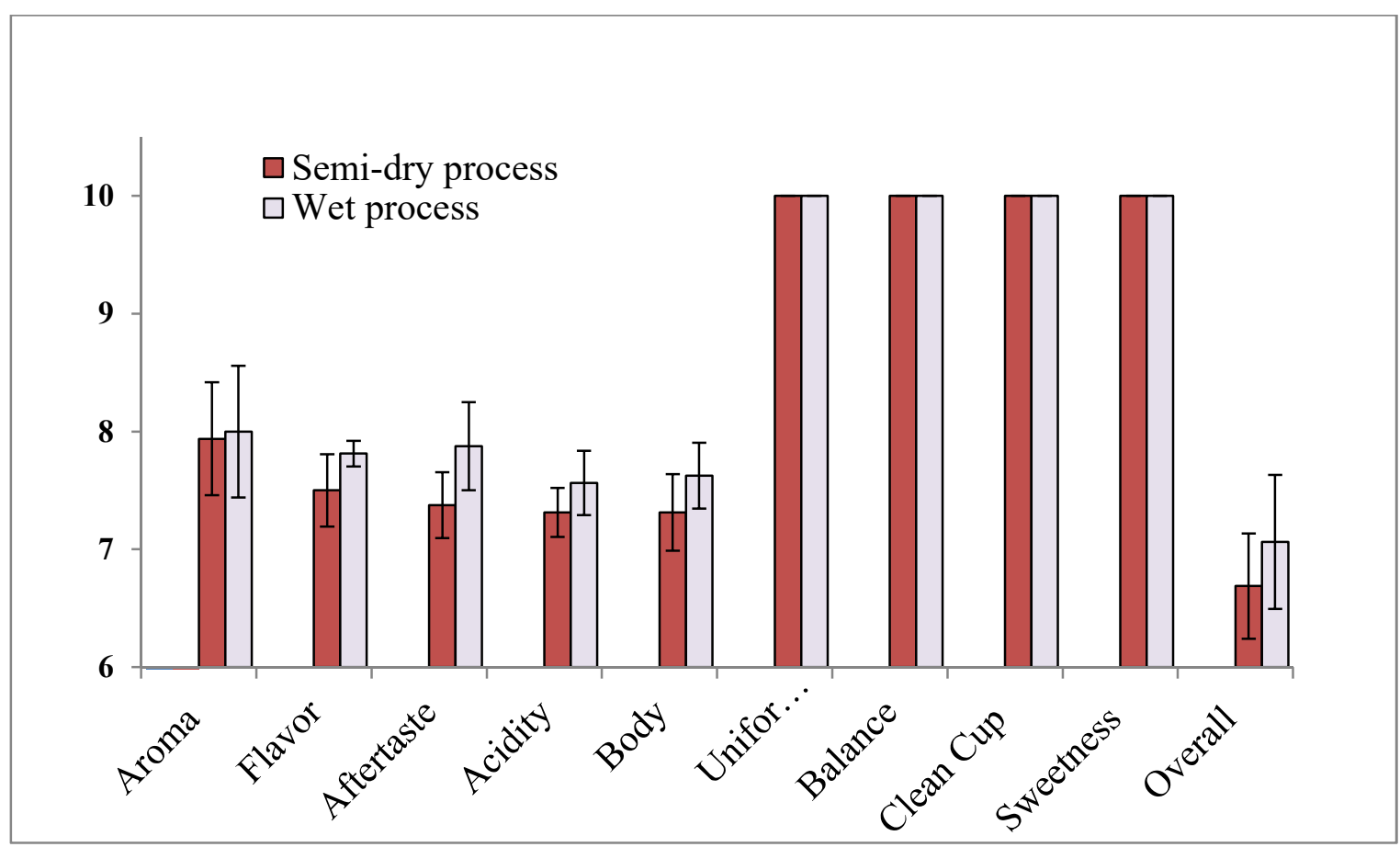

FIGURE 2. Average score of the attributes evaluated in the samples of Castillo coffee with wet and semi-dry processing method. Mean values $\pm \mathrm{SD}(\mathrm{n}=10)$. Bars indicate the standard deviation. 


\section{CONCLUSIONS}

The wet and semi-dry processing methods showed differences in color parameters, $\mathrm{pH}$ values, and caffeine content. However, neither the observed physicochemical parameters nor sensory evaluation showed any difference between the wet and semi-dry processing methods. Therefore, the type of coffee processing method has no effect on the final chemical properties of the roasted coffee, of the Castillo variety evaluated in this study, nor does it affect the cup score. The ATR-FTIR technique differentiated between green coffee and roasted coffee, and the HPLC-UV technique allowed for quantifying and distinguishing between the two levels of roasting.

\section{ACKNOWLEDGMENTS}

The authors gratefully acknowledge the financial support of the Centro Surcolombiano de Investigación en Café CESURCAFÉ and the Universidad Surcolombiana (USCO).

\section{REFERENCES}

Alvarado G, Posada E, Cortina A (2005) Castillo nueva variedades de café con resistencia a la roya. Avances técnicos Cenicafé 337:1-8.

AOAC - Official Methods of Analysis (1995) Method 920.92. Washington.

Barjolle D, Quiñones X, Bagal M, Comoe H (2017) The Role of the State for Geographical Indications of Coffee: Case Studies from Colombia and Kenya. World Dev 98:105-19. DOI:

http://dx.doi.org/10.1016/j.worlddev.2016.12.006

Burdan F (2015) Caffeine in Coffee, In: Preedy VR (Ed). Coffee in health and disease prevention. San Diego, Academic Press, Cap 22, p 201-207.

DOI: http://dx.doi.org/10.1016/B978-0-12-4095175.00022-X

Craig A, Franca A, Oliveira L (2012) Discrimination between defective and non-defective roasted coffees by diffuse reflectance infrared Fourier transform spectroscopy. LWT-Food Science Technology 47:505511. DOI: http://dx.doi.org/10.1016/j.lwt.2012.02.016

Craig A, Franca A, Oliveira L, IrudaYaraj J, Ileleji K (2014) Application of elastic net and infrared spectroscopy in the discrimination between defective and non-defective roasted coffees. Talanta 128:393-400.

DOI: http://dx.doi.org/10.1016/j.talanta.2014.05.001

Craig A, Franca A, Oliveira L, IrudaYaraj J, Ileleji K (2015) Fourier transform infrared spectroscopy and near infrared spectroscopy for the quantification of defects in roasted coffees. Talanta 134:379-386.

DOI: http://dx.doi.org/10.1016/j.talanta.2014.11.038

Clifford M (2000) Review: Chlorogenic acids and other cinnamates-nature, occurrence and dietary burden. Journal of the Science of Food and Agriculture 80:1033-1043. DOI: http://dx.doi.org/10.1002/(SICI)10970010(19990301)79:3<362::AID-JSFA256>3.0.CO;2-D
Dadi D, Mengistie E, Terefe G, Getahun T, Haddis A, Birke W, Beyene A, Luis P, Van der Bruggen B (2018) Assessment of the effluent quality of wet coffee processing wastewater and its influence on downstream water quality. Ecohydrology \& Hydrobiology 18:201-211. DOI: https://doi.org/10.1016/j.ecohyd.2017.10.007

Daglia M, Papetti A, Gregotti C, Bertè F, Gazzani G (2000) In vitro antioxidant and ex vivo protective activities of green and roasted coffee. Journal of Agricultural and Food Chemistry 48:1449-1454.

DOI: http://dx.doi.org/10.1021/jf990510g

Dias E, Valderrama P, Dos Santos M, Edelmann, M, Yeretzian C (2018) Quantitative assessment of specific defects in roasted ground coffee via infrared-photoacoustic spectroscopy. Food Chemistry 255:132-138. DOI:http://dx.doi.org/10.1016/j.foodchem.2018.02.076

Di Donfrancesco B, Gutierrez N, Chambers E (2019) Similarities and differences in sensory properties of high quality Arabica coffee in a small region of Colombia. Food Research International 116:645-651.

DOI: http://dx.doi.org/10.1016/j.foodres.2018.08.090

Di Donfrancesco B, Gutierrez N, Chambers E (2014) Comparison of Results from Cupping and Descriptive Sensory Analysis of Colombian Brewed Coffee. Journal Sensory Study 29:301-311.

DOI: http://dx.doi.org/10.1111/joss. 12104

Duarte S, Pereira A, Farah A (2010) Chlorogenic acids and other relevant compounds in Brazilian coffees processed by semi-dry and wet post-harvesting methods. Food Chemistry 118:851-855. DOI:

http://dx.doi.org/10.1016/j.foodchem.2009.05.042

Duarte S, De Abreu C, Menezes H, Dos Santos M, Gouvea $\mathrm{C}$ (2005) Effect of processing and roasting on the antioxidant activity of coffee brews. Food Science and Technology 25:387-393.

DOI: http://dx.doi.org/10.1590/S010120612005000200035

Farah A, Duarte G (2015) Bioavailability and Metabolism of Chlorogenic Acids from Coffee, In Victor R. Preedy (Ed.) Coffee in Health and Disease Prevention. San Diego Academic Press. Cap 87, p 789-801.

DOI: http://dx.doi.org/10.1016/B978-0-12-4095175.00087-5

Farah A, De Paulis T, Trugo L, Martin PR (2005) Effect of roasting on the formation of chlorogenic acid lactones in coffee. Journal Agricultural Food Chemistry 53:15051513. DOI: http://dx.doi.org/10.1021/jf048701t

Federación Nacional de Cafeteros de Colombia (2019) Producción Colombiana de café. Available: https://www.federaciondecafeteros.org/clientes/es/quienes _somos/119_estadisticas_historicas/. Accessed: Oct, 2019.

Gallignani M, Torres M, Ayala C, Brunetto M (2008) Determination of caffeine in coffee by means Fourier transform infrared spectrometry. Revista Tecnología Ingeniera Universidad Zulia 31:1-11. 
Garg S (2016) Green coffee bean. In Ramesh C.

Nutraceuticals. Gupta, Academic Press, p 653-667.

DOI: http://dx.doi.org/10.1016/B978-0-12-8021477.00047-4

Han H, Soo, Ko S, Hyun B, Noh S, Hyung S (2017) Comparison of the antioxidant activities of roasted and explosive puffed coffees. Journal food science technology 52:1-8. DOI: http://dx.doi.org/10.1111/ijfs.13402

Hečimović I, Belščak-Cvitanović A, Horžić D, Komes D (2011) Comparative study of polyphenols and caffeine in different coffee varieties affected by the degree of roasting. Food Chemistry 129:991-1000.

DOI: http://dx.doi.org/10.1016/j.foodchem.2011.05.059.

Jeszka-Skowron M, Stanisz E, De Peña M (2016)

Relationship between antioxidant capacity, chlorogenic acids and elemental composition of green coffee. LWTFood Science Technology 73(2):243-50.

DOI: http://dx.doi.org/10.1016/j.lwt.2016.06.018

Ky C, Louarn J, Dussert S, Guyot B, Hamon S, Noirot M (2001) Caffeine, trigonelline, chlorogenic acids and sucrose diversity in wild Coffea arabica L. and C. canephora P. accessions. Food Chemestry 75:223-230. DOI: https://doi.org/10.1016/S0308-8146(01)00204-7

Mazzafera P (1999) Chemical composition of defective coffee beans Food Chemistry 64:547-54.

DOI: http://dx.doi.org/10.1016/S0308-8146(98)00167-8

Moon JK, Yoo HS, Shibamoto T (2009) Role of roasting conditions in the level of chlorogenic acid content in coffee beans: correlation with coffee acidity. Journal Agricultural Food Chemistry 57:5365-5369.

DOI: http://dx.doi.org/https://doi.10.1021/jf900012b

Liang N, Xue W, Kennepohl P, Kitts D (2016) Interactions between major chlorogenic acid isomers and chemical changes in coffee brew that affect antioxidant activities. Food Chemistry 213:251-59.

DOI: http://dx.doi.org/10.1016/j.foodchem.2016.06.041.

Lee L, Tay G, Cheong M, Bin P, Liu S (2017) Modulation of the volatile and non-volatile profiles of coffee fermented with Yarrowia lipolytica: II. Roasted coffee. LWT- food science and technology 80:32-42. DOI: http://dx.doi.org/10.1016/j.lwt.2017.01.070
Lyman D, Benck R, Dell S, Merle S, Murray-Wijelath J (2003) FTIR-ATR Analysis of Brewed Coffee: Effect of Roasting Conditions. Journal Agricultural Food Chemistry 51:3268-3272. DOI: http://dx.doi.org/10.1021/jf0209793

Reis N, Franca A, Oliveira L (2013) Performance of diffuse reflectance infrared Fourier transform spectroscopy and chemometrics for detection of multiple adulterants in roasted and ground coffee. LWT-Food Science Technology 53:395-401.

DOI: http://dx.doi.org/10.1016/j.lwt.2013.04.008

Ribeiro J, Salva T, Ferreira M (2010) Chemometric studies for quality control of processed Brazilian coffees using drifts. Journal Food Quality 33:212-227.

DOI: http://dx.doi.org/10.1111/j.1745-4557.2010.00309.x

Specialty Coffee Association of America [SCAA] (2015). SCA Protocols: cupping specialty coffee, United States. From: http://scaa.org/?page=resources\&d=cuppingprotocols

Tolessa K, Rademaker M, De Baets B, Boeckx P (2016) Prediction of specialty coffee cup quality based on near infrared spectra of green coffee beans. Talanta 150:367374. DOI:http://dx.doi.org/10.1016/j.talanta.2015.12.03

Vellema W, Buritiva A, González C, D’Haese M (2015) The effect of specialty coffee certification on household livelihood strategies and specialization. Food Policy 1:325. DOI: http://dx.doi.org/10.1016/j.foodpol.2015.07.003

Worku A, De Meulenaer B, Duchateau L, Boeckx P (2017) Effect of altitude on biochemical composition and quality of green arabica coffee beans can be affected by shade and postharvest processing method. Food Research International 105:278-285.

DOI: http://dx.doi.org/10.1016/j.foodres.2017.11.016

Wang X, LIM L (2015) Physicochemical Characteristics of Roasted Coffee, In Victor R. Preedy, Academic Press (Ed) Coffee in Health and Disease Prevention. San Diego, p 247-254. DOI: http://dx.doi.org/10.1016/B978-0-12409517-5.00027-9 